\title{
HER-2/neu immunoreactivity in invasive mammary carcinomas: a comparative study using monoclonal and polyclonal antibodies including the HercepTest ${ }^{\mathrm{TM}}$
}

\author{
Imunorreatividade do HER-2/neu em carcinomas mamários invasivos: estudo comparativo usando \\ anticorpos mono e policlonais, incluindo o HercepTest $^{T M}$
}

Agostinho Pinto Gouvêa'; José Roberto Maggi Fernandes'; Sandra Jean Olson ${ }^{3}$; Eduardo de Carvalho Brandão ${ }^{4}$ Miguel Torres Leite ${ }^{5}$; Helenice Gobbi ${ }^{6}$

\begin{abstract}
key words abstract
Breast cancer

HER-2/neu

Introduction: HER-2/neu overexpression has been tested using immunohistochemistry as a reliable and cost-effective method to select patients with invasive mammary carcinomas (IMC) for trastuzumab treatment, but there is no consensus regarding the best antibody to be used. The aim of the present study was to test five different antibodies c-erbB-2 for determining the status of HER-2/neu overexpression in IMC. Material and methods: Sixty-six formalin-fixed, Immunohistochemistry paraffin-embedded IMC were investigated by immunohistochemistry, using two polyclonal antibodies, HercepTest ${ }^{\mathrm{T} M}$ (Dako) and A0485 (Dako), and three monoclonal antibodies, the clone CB11, from both Novocastra Laboratories Pathology and from Biogenex, and the clone 4D5 (Genentech). All immunostainings were scored according to the guidelines for the HercepTest ${ }^{\mathrm{TM}}$. Results: The A0485 was positive in 25 cases (37.9\%). The HercepTest ${ }^{\mathrm{TM}}$ was positive in 14/66 cases (21.2\%). Both CB11 antibodies yielded a positive reaction in the same nine patients (13.6\%). The 4D5 was positive in only $4 / 66$ cases (6.1\%). All positive cases for CB11 or 4D5 were HercepTest ${ }^{\mathrm{TM}}$ positive. All cases positive

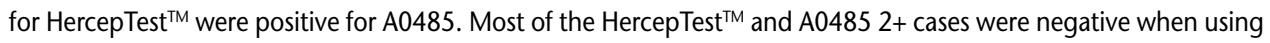
the other antibodies. Discussion: There was a higher number of cases presenting HER-2/neu positivity with the A0485 and HercepTest ${ }^{\mathrm{TM}}$ than with the other antibodies, primarily in cases scored as $2+$. There was no difference in positivity when the CB11Ab was used, regardless of company. Conclusion: The use of immunohistochemistry for the clinical assessment of HER-2/neu overexpression still needs prospective validation.
\end{abstract}

Introdução: A superexpressão de HER-2/neu tem sido testada por imunoistoquímica como um método seguro e de baixo custo para selecionar pacientes com carcinoma mamário invasivo (CMI) para tratamento com trastuzumab, entretanto não há consenso sobre qual o melhor anticorpo a ser utilizado. O objetivo deste trabalho foi testar cinco diferentes anticorpos para determinar a superexpressão do HER-2/neu em CMI. Material e métodos: Sessenta e seis casos de CMI fixados em formalina e incluídos em parafina foram submetidos a imunoistoquímica, utilizando-se dois anticorpos policlonais: HercepTest $^{T M}$ (Dako) e A0485 (Dako), e três anticorpos monoclonais: CB11 de Novocastra Laboratories e da Biogenex e 4D5 (Genentech). Todas as reações imunoistoquímicas foram interpretadas de acordo com as instruções do HercepTest ${ }^{T M}$. Resultados: 0 A0485 foi positivo em 25/66 casos (37,9\%). O HercepTest ${ }^{T M}$ foi positivo em 14/66 casos (21,2\%). Houve concordância integral nos casos corados com CB11 de ambos os fabricantes: 9/66 (13,7\%). O 4D5 foi positivo em somente 4/66 casos (6,1\%). Todos os casos positivos para CB11 e 4D5 foram positivos para o HercepTest ${ }^{T M}$. Todos os casos HercepTest ${ }^{T M}$ foram positivos para o A0485. A maioria dos casos 2+ para o HercepTest ${ }^{T M}$ e A0485 foi negativa com os outros anticorpos. Discussão: Houve maior incidência de superexpressão do HER-2/neu com o HercepTest ${ }^{T M}$ e o A0485 do que com os anticorpos monoclonais, principalmente nos casos classificados como 2+. Não houve diferença na imunorreatividade usando-se o anticorpo CB11 dos dois diferentes fabricantes. Conclusão: $O$ uso clínico da imunoistoquímica para determinar a superexpressão do HER-2/neu necessita ainda de validações prospectivas.

1. Anatomopathologist; Ph.D. in Pathology; Department of Anatomic Pathology; School of Medicine, Federal University of Minas Cerais.

2. Medicine student; scientific initiation scholar by CNPq; Department of Anatomic Pathology; School of Medicine, Federal University of Minas Cerais.

3. Master in Science; assistant instructor at the Department of Pathology, Vanderbilt University, Tennessee, USA.

4. Clinical oncologist; Clinical Oncology Unit, Santa Casa de Misericórdia de Belo Horizonte.

5. Radioncologist; Radioncologisty Unit, Santa Casa de Misericórdia de Belo Horizonte.

6. Assistant professor; Ph.D. in Pathology; Department of Anatomic Pathology, School of Medicine, Federal University of Minas Cerais.

Work developed at Laboratory of Breast Pathology, Department of Anatomic Pathology; School of Medicine, Federal University of Minas Cerais (UFMC). It is part of Ph.D. thesis of Agostinho Pinto Couvêa supervised by prof. Helenice Cobbi, in the postgraduate program of Pathology, UFMG, presented on 2/25/03. Partial results of this work were presented as oral presentation in $24^{\text {th }}$ International Congress of the International Academy of Pathology, Amsterdam, th

April 30 to May 3, 2003. This work was supported in part by Fapemig (CDS-560/01) and CNPq (520117/00-0-NV). 


\section{Introduction}

The HER-2/neu gene is variously known as neu, HER-2, and c-erbB-2. A mutated HER-2 version was first identified in rat neuroglioblastomas, and hence named the gene neu. Three distinct laboratories discovered the gene by searching for genes related to the epidermal growth factor receptor (EGFR) and hence named the gene HER-2/neu (human EGFR-related gene) or c-erbB-2 (because the EGFR gene was known as the c-erbB1 gene) ${ }^{(10)}$. The HER family plays an important role in regulating cell growth, oncogenic transformation, tumorigenesis, and metastasis ${ }^{(11,22,23)}$. Overexpression of the HER-2/neu occurs in $20 \%$ to $30 \%$ of invasive mammary carcinomas and is correlated with a more aggressive phenotype ${ }^{(2,9-11,14)}$. Slamon et al. ${ }^{(25)}$ revealed that HER-2/neu gene amplification independently predicted overall survival and disease-free survival in node-positive patients. Since then, larger studies have confirmed HER-2/neu status as a significant independent predictor of prognosis in node-positive patients ${ }^{(27,28)}$. There is also a possibility that HER-2/neu status may be useful in determining invasive potential in patients with ductal carcinoma in situ (DCIS), since HER-2/neu overexpression is very common in high-grade, comedotype $\operatorname{DCIS}^{(1,11)}$.

The pathologist plays a central role in the accurate diagnosis of breast cancer and in the subsequent assessment of prognostic and predictive factors that assist in treatment and management decisions. The primary prognostic factors in breast cancer remain those determined by clinical or standard pathological approaches: axillary lymph node status, tumor size, histological and nuclear grade, and histological subtype ${ }^{(1,13)}$. Although predictive factors are more valuable clinically, the only clearly validated predictive factors are estrogen receptor and progesterone receptor status ${ }^{(13)}$. HER-2/neu has been the focus of intensive study over the past decade ${ }^{(11,12,18)}$. The importance of the role of HER-2/neu has increased with the release of trastuzumab (Herceptin), a humanized antibody against HER-2/neu that is being used to treat breast cancer

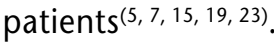

In spite of the release of the drug there is no agreement as to the best method of assessing amplification

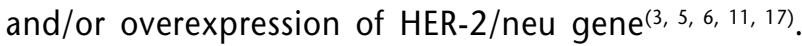
HER-2/neu can be measured in different ways: 1) oncoprotein overexpression: this can be performed by immunohistochemistry (IHC), Elisa, or Western blot $^{(3,5,6,12,17)}$; 2) gene amplification: this can be performed by Southern hybridization, polymerase chain reaction (PCR), fluorescence in situ hybridization (FISH) $)^{(3,}$ $5,17,20)$, or by chromogen in situ hybridization $(\mathrm{CISH})^{(29)}$; 3) mRNA by Northern blot ${ }^{(15)}$. It becomes important to develop a reliable and sensitive test to identify patients with HER-2/neu-overexpression tumors to optimize their treatment ${ }^{(5,15-17)}$.

IHC for HER-2/neu protein expression is the most attractive routine test based on issues of cost, convenience, and biological relevance ${ }^{(19,21,26)}$. However, problems with variability in IHC staining have been reported. Specifically, differences in sensitivity and specificity among the various commercially available antibodies, variability in interpretation, and technical $\operatorname{artifact}^{(21,26)}$. The aim of this study is to assess the performance of IHC on formalin-fixed, paraffinembedded tissue from invasive mammary carcinomas, using different antibodies that can be used in routine diagnostic pathology laboratories.

\section{Material and methods}

\section{Patients}

The materials analyzed were obtained from primary tumors of patients with invasive mammary carcinoma, who had undergone surgery, either modified mastectomy or lumpectomy, in Hospital das Clínicas da UFMG or Santa Casa de Misericórdia de Belo Horizonte, Minas Gerais. All patients had tumors measuring from 2 to $5 \mathrm{~cm}$ with no lymph node involvement (T2N0). Tumor samples consisted of 66 formalin-fixed, paraffin-embedded tissue blocks routinely processed, from institutional archives. For each case, six consecutive sections were obtained and placed on silanized slides. The first section was stained by hematoxylineosin to confirm that areas of invasive mammary carcinoma were identified. The status of HER-2/neu was assayed by immunohistochemistry on the other five consecutive $4-\mu \mathrm{m}$ tissue sections.

\section{HER-2/neu antibodies}

Two polyclonal antibodies - HercepTest ${ }^{\mathrm{TM}}$ (Dako) and A0485 (Dako) - and three monoclonal antibodies - CB11, from both Novocastra Laboratories (NCL-CB11) and Biogenex (Biogenex-CB11), and 4D5 (Genentech) - were tested for immunostaining using the tissue sections (Table 1). 
Table 1 Antibodies, dilutions, antigen retrieval methods used, and antibodies sources

\begin{tabular}{lcccc}
\hline Antibody type & Clone/kit & Dilution & Antigen retrieval/time & Source \\
Polyclonal & HercepTest'm & Pre-diluted & Water bath/40min & Dako/USA \\
Polyclonal & A0485 & $1: 700$ & Steamer/25min & Dako/USA \\
Monoclonal & CB11 & $1: 80$ & No pretreatment & Novocastra/UK \\
Monoclonal & CB11 & Pre-diluted & No pretreatment & Biogenex/USA \\
Monoclonal & LD5 & $1: 200$ & Trypsin & Genentech/USA \\
\hline
\end{tabular}

\section{Immunohistochemical technique}

All staining for HER-2/neu protein expression was performed manually. The Dako HercepTest ${ }^{\mathrm{TM}}$ kit was used according to the protocol of the manufacturer's guide. The other antibodies were applied after deparaffinization and rehydration of the sections, endogenous peroxidase was inhibited by a 20 -min incubation in $0.3 \% \mathrm{H}_{2} \mathrm{O}_{2}$ in distilled water. Heat-induced antigen retrieval using a steamer (25-min in citrate buffer, $10 \mathrm{mM}, \mathrm{pH} 6.0$ ) was used for A0485, and a trypsin (Sigma) treatment was used for the 4D5 antibody. No pretreatment was done for the cases stained with CB11 monoclonal antibodies. For uniformity, the stainings were completed with the streptavidin-biotin peroxidase detection system from Biogenex Laboratories (USA), and 3,3'-diaminobenzidine chromogen solution (Liquid DAB, Dako, USA). Sections were counterstained with hematoxylin. Optimal dilutions of the antibodies were determined by serial antibody dilutions with immunohistochemical testing and/or use of optimal conditions as described in the literature or in the specification sheet provided by suppliers (Table 1). Positive and negative controls were included in each assay. The pellet control supplied with the kit was used for the HercepTest ${ }^{\mathrm{TM}}$.

\section{Interpretation of staining}

For the determination of HER-2/neu protein overexpression, only the membrane staining intensity of the invasive component in hot spot areas was considered. Two pathologists using a double-headed light microscope performed each slide evaluation. All immunostainings were reviewed and scored according to the guidelines for the HercepTest ${ }^{\mathrm{TM}}$. Cytoplasmic staining was considered nonspecific staining and was not included in the assessment of membrane staining intensity. To aid in the differentiation of $1+, 2+$, and 3+ staining, the Dako's Atlas for the Interpretation of HercepTest ${ }^{\mathrm{TM}}$, provided with the kit, with representative pictures of the staining intensities, was used.

\section{Results}

The immunohistochemical analysis of the four antibodies is summarized in Table 2, and Figures 1 and 2. The A0485 was positive in $25 / 66$ cases (37.9\%). The HercepTest ${ }^{\mathrm{TM}}$ was positive in $14 / 66$ cases (21.2\%). The 4D5 was positive in only $4 / 66$ cases (6.1\%). There was total agreement in stained cases using the CB11 from either Novocastra or Biogenex: $9+/ 66$ cases (13.6\%). All positive

Results of HER-2/neu testing by immunohistochemistry considering the score obtained Table 2 for different antibodies

\begin{tabular}{cccccc}
\hline \multicolumn{5}{c}{ Polyclonal } & HER-2/neu antibodies \\
IHC & A0485 & Ab4D5 & NCL-CB11 & Biog-CB11 \\
scores & HercepTest ${ }^{\text {TM }}$ & $25(37.9 \%)$ & $61(92.4 \%)$ & $55(83.3 \%)$ & $55(83.3 \%)$ \\
0 & $50(75.8 \%)$ & $16(24.2 \%)$ & $1(1.5 \%)$ & $2(3 \%)$ & $2(3 \%)$ \\
$1+$ & $2(3 \%)$ & $14(21.2 \%)$ & $1(1.5 \%)$ & $3(4.5 \%)$ & $3(4.5 \%)$ \\
$2+$ & $6(9.1 \%)$ & $11(16.7 \%)$ & $3(4.5 \%)$ & $6(9.1 \%)$ & $6(9.1 \%)$ \\
$3+$ & $8(12.1 \%)$ & $66(100 \%)$ & $66(100 \%)$ & $66(100 \%)$ & $66(100 \%)$ \\
Total & $66(100 \%)$ & & & & \\
\hline
\end{tabular}




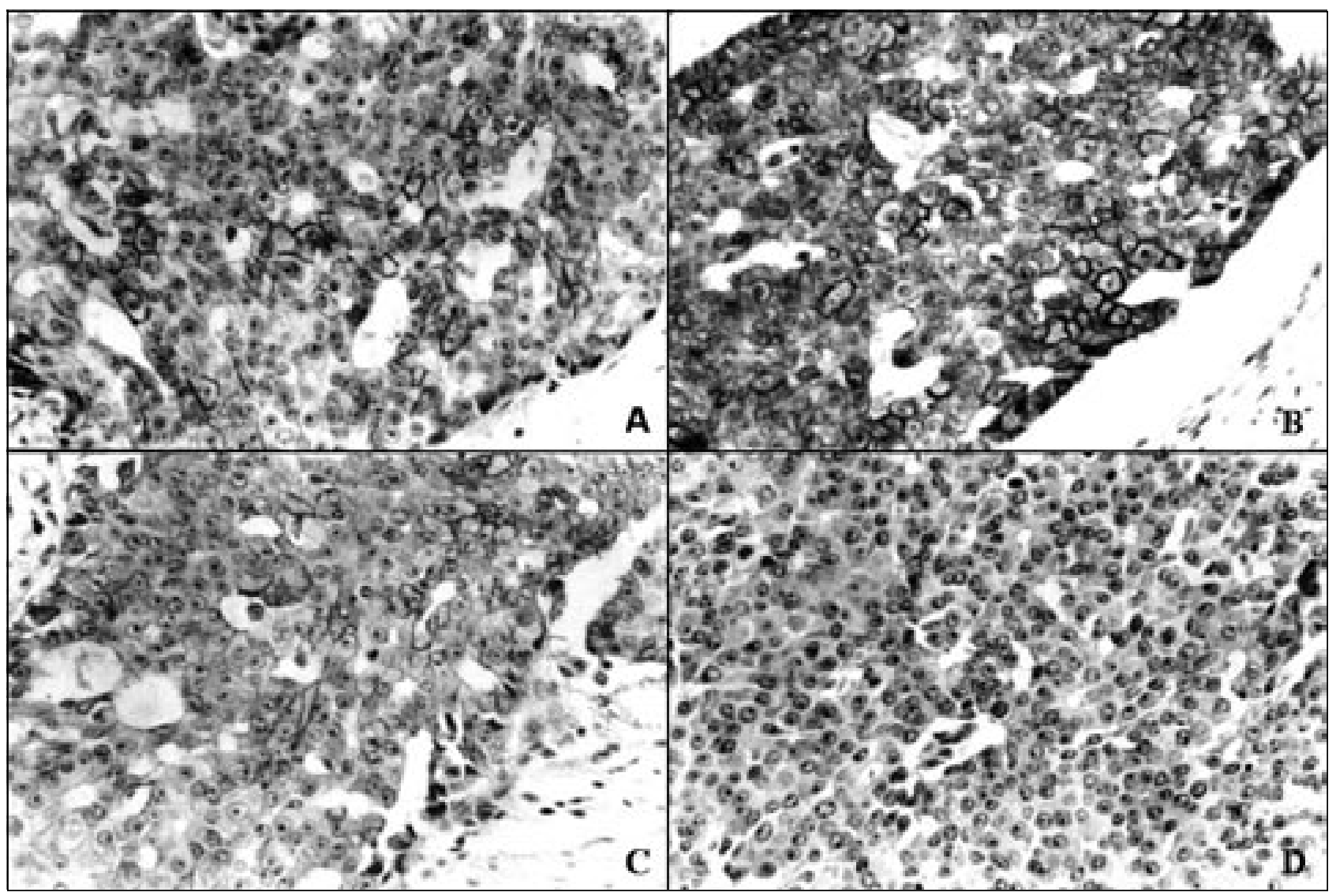

Figure 1 - Different results of immunostaining for HER-2/neu in the same case of invasive mammary carcinoma (NOS). A: Hercep Test ${ }^{T M}\left(3^{+}\right)$; B: A0485( $\left.3^{+}\right)$: C: Novocastra-CB11 $\left(2^{+}\right)$; D: 4D5 (negative) (200X)

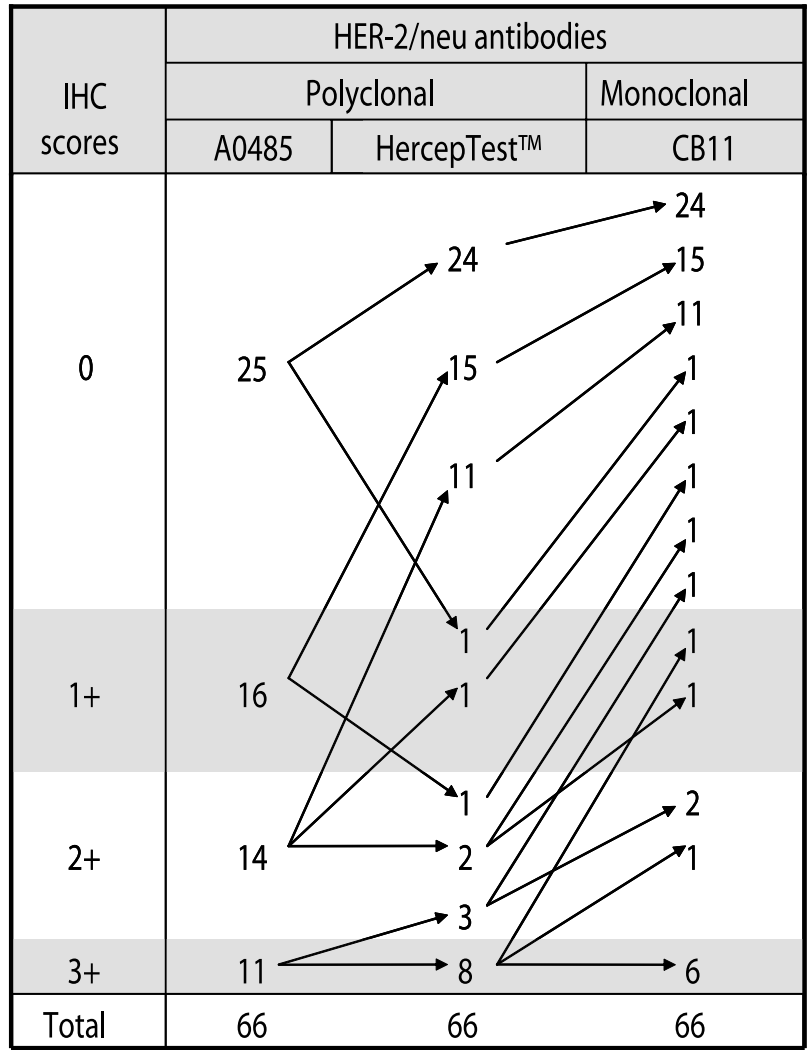

Figure 2 - Distribution of results of immunostainings for HER-2/neu considering the score obtained using commercial antibodies cases for CB11 or Ab4D5 were HercepTest ${ }^{\mathrm{TM}}$ positive. All positive cases for HercepTest ${ }^{\mathrm{TM}}{ }^{\mathrm{M}}$ were $\mathrm{A} 0485$ positive. Most of the HercepTest $2+$ cases were negative when using the other antibodies. There was a higher incidence of HER-2/neu overexpression with the A0485 and HercepTest ${ }^{\mathrm{TM}}$ than with the other antibodies, primarily in cases scored as $2+$.

Nonspecific cytoplasmic staining was observed in 32 cases stained with A0485, in spite of the high dilution used, in eight cases stained with NCL-CB11, five cases stained with $4 \mathrm{D} 5$, in two cases with HercepTest ${ }^{\mathrm{TM}}$, and in one case with the Biogenex-CB11. Most of the cases with cytoplasmic staining showed no membrane staining. Edge artifacts and nonspecific staining of stroma were also seen in a few cases.

\section{Discussion}

In the present study, we examined the expression of HER-2/neu in archival paraffin-embedded specimens $(n=66)$ of IHC, testing tumor from the same patients using the HercepTest ${ }^{\mathrm{TM}}$ and four other antibodies. We found great variability in the HER-2 overexpression detected 
using the different antibodies. Similar to our results, other authors have described variability in the $\mathrm{IHC}$ results using different common commercially available antibodies ${ }^{(14,}$ 15, 17, 26). Thomson et al. ${ }^{(26)}$ analyzed the interobserver variability and performance of immunohistochemistry using four antibodies (HercepTest ${ }^{\mathrm{TM}}$, A0485, TAB250, and CB11), compared with FISH. They found fair concordance between IHC and FISH with three of the four antibodies tested in their study. Stain scores of 0 and $3+$ were highly predictive of gene status. In cases with stain intensity of $1+$ or $2+$, the interobserver agreement was poor, and the predictive value was unsatisfactory for clinical use. The authors concluded that additional testing for these cases, preferably using FISH, is recommended. Ganceberg et al. ${ }^{(14)}$ evaluated the sensitivity of three HER-2/neu antibodies in archival tissue samples of invasive mammary carcinomas and correlated with oncogene amplification assessed by FISH in 160 cases. They found significant variability in sensitivity among three commonly used antibodies, and consequently considered these techniques less reproducible than FISH. The authors considered that in addition to the choice of the antibody, the great variability in antigen retrieval, tissue fixation, and detection methods make it difficult to compare results from multicenter studies ${ }^{(14)}$.

The study of Jacobs et al. ${ }^{(16)}$ using a standardized immunohistochemical method and a single antibody resulted in good reproducibility in paraffin-embedded tissue sections. They demonstrated equivalence of IHC results compared with FISH method for evaluation of HER-2/neu in breast cancer, and recommended immunohistochemistry as a less time-consuming and less expensive method for routine use in laboratories. However, other studies have stressed the variability of the sensitivity of HER-2/neu antibodies as a potential source of error in the assessment of the expression of the gene $(14,20,21,26)$. The present controversy about the reliability of a US Food and Drug Administration-approved HER-2/neu IHC test illustrates that this issue remains incompletely solved ${ }^{(16,19)}$. Yet, the recently introduced therapeutic approaches, based on monoclonal antibodies and on antisense oligonucleotides, that target tumor cells overexpressing HER-2/neu require an accurate assessment of the status of the gene before inclusion of patients in such protocols $s^{(4,8,17)}$. These reasons indicate the necessity to calibrate IHC with the aid of a reference technique, which could be $\mathrm{FISH}^{(5,8,23,24)}$ or $\mathrm{CISH}^{(29)}$. Other authors also consid ered FISH a useful methodology for confirmation of ambiguous $\mathrm{IHC}$ results $(2+)$ and $\mathrm{IHC}$ positive cases $^{(8,19)}$.

In conclusion, our results and data from the literature showing immunohistochemical variability in the same cases when different antibodies are used may have important clinical implications and indicate that the clinical use of immunohistochemistry in determining HER-2/neu overexpression still needs prospective validation.

\section{Acknowledgements}

To David Page, MD, for providing some reagents and the antibody 4D5, and Indelécio Garcia Chaves, $M D$, for providing clinical data. This work was supported in part by Fapemig (CDS-560/01) and CNPq (520117/00-0).

\section{References}

I. ALLRED, D. C. et al. Overexpression of HER/neu and its relationship with other prognostic factors change during the progression of in situ to invasive breast cancer. Hum Pathol, v. 23, p. 974-9, 1992.

2. ANDRULIS, I. L. et al. Neu/erbB-2 amplification identifies a poor-prognosis group of women with node-negative breast cancer.J Clin Oncol, v. I6, p. 1340-9, 1998.

3. BÁNKFALVI, A. et al. Comparative methodological analysis of erbB-2/HER-2 gene dosage, chromosomal copy number and protein overexpression in breast carcinoma tissues for diagnostic use. Histopathology, v. 37, p. 41 I-9, 2000.

4. BASELGA, J. et al. Phase II study of weekly intravenous recombinant humanized anti-p $185^{\text {her2 }}$ monoclonal antibody in patients with HER-2/neu-overexpressing metastatic breast cancer.J Clin Oncol, v. I4, p. 737-44, 1996.
5. BLEIWEISS, I. J.To Fish or not to Fish: the HER-2/neu debate goes on. Adv Anat Pathol, v. 9, p. I43-4, 2002.

6. BUSMANI, I. et al. Analysis of c-erbB-2 expression using a panel of six commercially available antibodies. Pathology, v. 26, p. 26I-7, 1994

7. CARLOMAGNO, C. et al. c-erbB-2 overexpression decreases the benefit of adjuvant tamoxifen in early-stage breast cancer without axillary lymph node metastases. J Clin Oncol, v. I4, p. $2702-8,1996$

8. COUTURIER, J. et al. Strong correlation between results of fluorescent in situ hibridization and immunohistochemistry for the assessment of the erbB2 (HER-2/neu) gene status in breast carcinomas. Mod Pathol, v. I3, p. 1238-43, 2000.

9. DE POTTER, C. R.; SCHELFHOUT, A. M. The neu-protein and breast cancer. Virch Arch, v. 426, p. I07- I5, 1995. 
10. DIGIOVANNA, M. P. Clinical significance of HER-2/neu overexpression: Part I. Princ Pract Oncol, v. I3, p. I-10, 1999.

I I. DOWSETT, M. et al. Assessment of HER-2 status in breast cancer: why, when and how? Eur J Cancer, v. 36, p. 170-6, 2000.

12. DYKINS, R. et al. Long-term survival in breast cancer related to overexpression of the c-erbB-2 oncoprotein: an immunohistochemical study using monoclonal antibody NCL-CBI I.J Pathol, v. 163, p. 105-10, 1991.

13. FITTZGOBBONS, P. L. et al. Prognostic factor in breast cancer. College ofAmerican Pathologists Consensus Statement 1999. Arch Pathol Lab Med, v. 124, p. 966-78, 2000.

14. GANCEBERG, D. et al. Sensitivity of HER-2/neu antibodies in archival tissue samples of invasive breast carcinomas. Correlation with oncogene amplification in 160 cases. Anat Pathol, v. II 3, v. 675-82, 2000.

15. HANNA, W. M. et al. Defining a test for HER-2/neu evaluation in breast cancer in the diagnostic setting. Mod Pathol, v. 14, p. 677-85, 2001.

16. JACOBS, T. W. et al. Specificity of HercepTest in determining HER-2/neu status of breast cancers using the United States Food and Drug Administration-approved scoring system. J Clin Oncol, v. 17, p. 1983-7, 1999.

17. JIMENEZ, R. E. et al. Determination of HER-2/neu status in breast carcinoma: comparative analysis of immunohistochemistry and fluorescent in situ hybridization. Mod Pathol, v. I3, p. 37-45, 2000.

18. O'MALLEY, F. P. et al. The predictive power of semiquantitative immunohistochemical assessment of p53 and c-erbB-2 in lymph node-negative breast cancer. Hum Pathol, v. 27, p. 955-63, 1996.

19. PEREZ, E. A. et al. HER2 testing in patients with breast cancer: poor correlation between weak positivity by immunohistochemistry and gene amplification by fluorescence in situ hybridization. Mayo Clin Proc, v. 77, p. | 148-54, 2002.

20. PRESS, M. F. et al. HER-2/neu gene amplification characterized by fluorescence in situ hybridization: poor prognosis in node-negative breast carcinomas. J Clin Oncol, v. 15, p. 2894-904, 1997.

2I. PRESS, M. F. et al. Sensitivity of HER-2/neu antibodies in archival tissue samples: potential source of error in immunohistochemical studies of oncogene expression. Cancer Res, v. 54, p. 277I-7, 1994.

22. ROSS, J. S.; FLETCHER, J.A. HER-2/neu (c-erbB-2) gene and protein in breast cancer. Am J Clin Pathol, v. II2, S53-S57, 1999.

23. SAHIN, A. A. Biologic and clinical significance of HER-2/neu (c-erbB-2) in breast cancer. Adv Anat Pathol, v. 7, p. 158-66, 2000.

24. SCHNITT, S. J. Breast cancer in the $2^{\text {st }}$ century: Neu opportunities and neu challengers. Mod Pathol, v. 14 p. 213-8, 200|.

25. SLAMON, D. J. et al. Human breast cancer: correlation of relapse and survival with amplification of the HER-2/neu oncogene. Science, v. 235, p. 177-82, 1987.

26.THOMSON,T.A. et al. HER-2/neu in breast cancer: interobserver variability and performance of immunohistochemistry with four antibodies compared with fluorescent in situ hybridization. Mod Pathol, v. 14, p. 1079-86, 2001.

27. THOR, A. D. et al. Analysis of c-erbB-2 expression in breast carcinomas with clinical follow-up. Cancer Res, v. 49, p. 7|47-52, 1998.

28. YAMAUCHI, H.; STEARNS, V.; HAYES, D. F. When is a tumor marker ready for prime time? A case study of c-erbB-2 as a predictive factor in breast cancer.J Clin Oncol, v. 19, p. 2334-56, 2001.

29. ZHAO, J. et al. Determination of gene amplification by chromogenic in situ hybridization (Cish) in archival breast carcinoma. Mod Pathol, v. I5, p. 657-65, 2002.
Mailing address

Helenice Cobbi Departamento de Anatomia Patológica Faculdade de Medicina da UFMG Av. Alfredo Balena 190/5.000 CEP 30130-100 - Belo Horizonte-MG Tel.: (31) 3248-9788 Fax: (31) 3222-3987 e-mail: hgobbi@medicina.ufmg.br 